\title{
Corrigendum: DNA damage response inhibition at dysfunctional telomeres by modulation of telomeric DNA damage response RNAs
}

Francesca Rossiello, Julio Aguado, Sara Sepe, Fabio lannelli, Quan Nguyen, Sethuramasundaram Pitchiaya, Piero Carninci \& Fabrizio d'Adda di Fagagna

Nature Communications 8:13980 doi: 10.1038/ncomms13980 (2017); Published 27 Feb 2017; Updated 13 Apr 2017

In Supplementary Fig. 3d, the two columns of DAPI images associated with pATM and pS/TQ images were inadvertently swapped. The correct version of this figure appears below. 
a

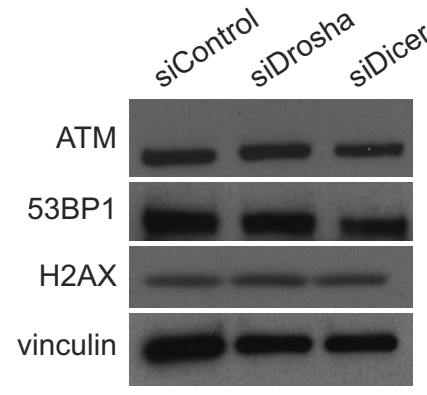

c
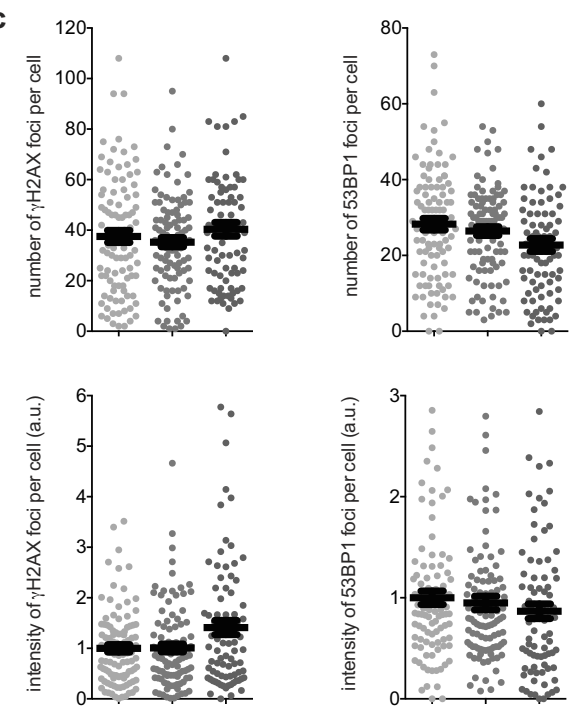
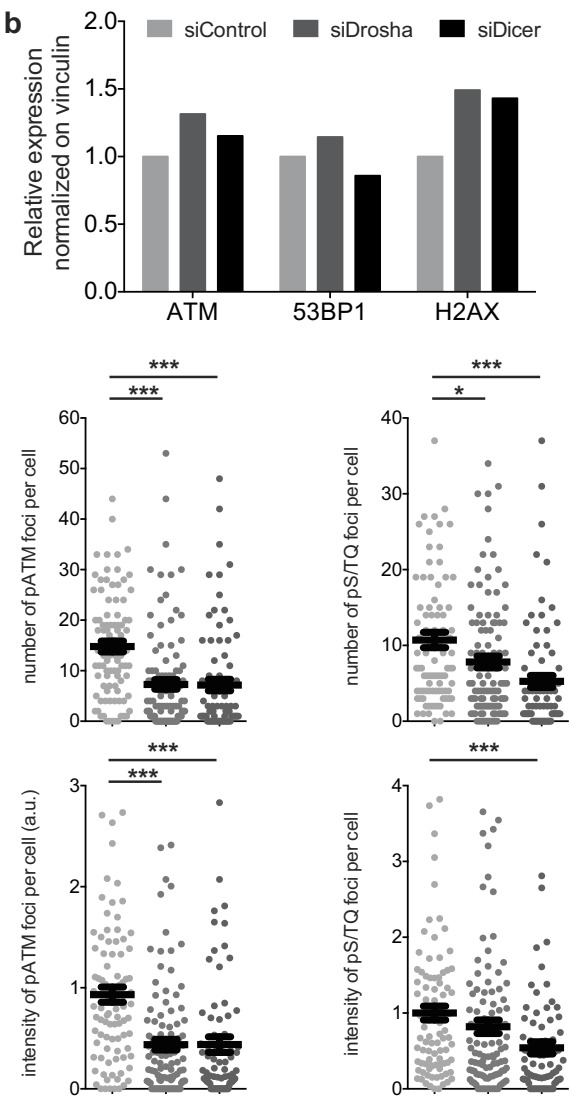

- siContro

- siDicer

d

TRF2 $\triangle B \triangle M$ - doxycycline

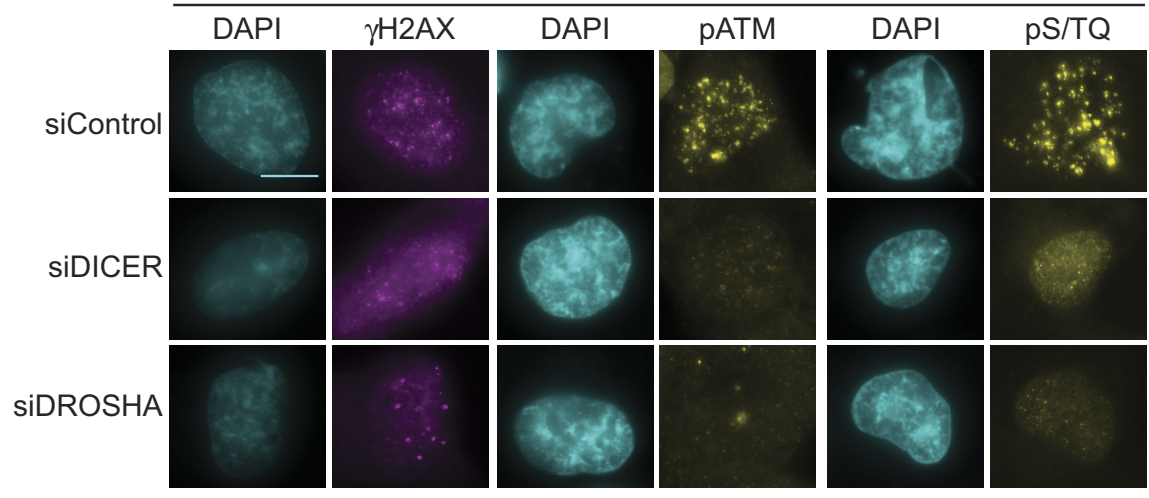

e
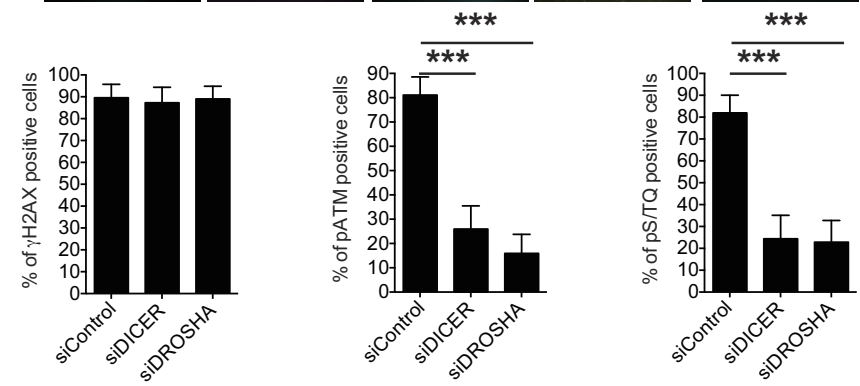

Figure 1

This work is licensed under a Creative Commons Attribution 4.0 International License. The images or other third party material in this article are included in the article's Creative Commons license, unless indicated otherwise in the credit line; if the material is not included under the Creative Commons license, users will need to obtain permission from the license holder to reproduce the material. To view a copy of this license, visit http://creativecommons.org/licenses/by/4.0/ 